\title{
THROWING LIGHT ON AN UNCOMMON PRESERVATION OF BLATTODEA FROM THE CRATO FORMATION (ARARIPE BASIN, CRETACEOUS), BRAZIL
}

\author{
FRANCISCO IRINEUDO BEZERRA \\ Programa de Pós-Graduação em Geologia, Departamento de Geologia, Universidade Federal do Ceará, \\ 64049-550, Fortaleza, CE, Brazil. \\ irineudoufc@gmail.com \\ JOÃO HERMÍNIO DA SILVA \\ Campus de Juazeiro do Norte, Universidade Federal do Cariri, 63000-000, Juazeiro do Norte, CE, Brazil. \\ herminio.silva@ufca.edu.br
}

\begin{abstract}
AMAURI JARDIM DE PAULA, NAIARA CIPRIANO OLIVEIRA, ALEXANDRE ROCHA PASCHOAL, PAULO TARSO C. FREIRE

Departamento de Física, Universidade Federal do Ceará, 60455-970, Fortaleza, CE, Brazil. amaurijp@fisica.ufc.br,naiara@fisica.ufc.br,paschoal@fisica.ufc.br,tarso@fisica.ufc.br

\section{BARTOLOMEU CRUZ VIANA NETO}

Departamento de Física, Universidade Federal do Piauí, 64049-550, Teresina, PI, Brazil. bartolomeu@ufpi.edu.br

MÁRCIO MENDES

Departamento de Geologia, Universidade Federal do Ceará, 64049-550, Fortaleza, CE, Brazil. paleonto@ufc.br
\end{abstract}

\begin{abstract}
Fossilization results from several physical-chemical-geological processes. Original labile and non-bioclastic structures rarely survive throughout this process. In particular, the Crato Formation (Araripe Basin) is one of the most significant Cretaceous KonservatLagerstätten due to its well-preserved invertebrates, mainly three-dimensional insects. In general, Crato insects exhibit brown-orange color, constituted by goethite or hematite replacements. In this context, we used the scanning electron microscopy coupled to energy dispersive spectrometer and Raman spectroscopy to analyze Araripeblatta dornellesae, a 115 million-years-old fossil from Crato Formation, Araripe Basin. Our results show that a dark-color material rather than the brown-orange pattern preserve this specimen. The carbon is restricted to the fossil imprint, indicating some retention of the original organic remains. In addition, the presence of original organic components allowed to approach the biochemical aspects further than simple morphology, as well as to elucidate the taphonomical complexity involved in this preservation style.
\end{abstract}

Keywords: taphonomy, Lower Cretaceous, Crato Formation, Lagerstätten, organic components, Scanning Electron Microscopy.

RESUMO - O processo de fossilização é resultado de uma série de processos físico-químicos ao longo do tempo geológico, onde dificilmente estruturas orgânicas são preservadas. Particularmente, a Formação Crato (Bacia do Araripe) é um dos mais importantes Konservat-Lagerstätten do Cretáceo, devido à presença de invertebrados bem preservados, inclusive fósseis de insetos em três dimensões. De maneira geral, os insetos da Formação Crato apresentam coloração marrom ou laranja, substituídos por goethita ou hematita. Neste contexto, utilizou-se microscopia eletrônica de varredura, espectroscopia de energia dispersiva e espectroscopia Raman para analisar Araripeblatta dornellesae, um fóssil de 115 milhões de anos. Este espécime apresenta coloração escura, em vez de padrão marrom/alaranjado. O elemento carbono aparece restrito a morfologia do fóssil indicando retenção de constituintes orgânicos. A presença de componentes orgânicos preservados pode, além da abordagem morfológica, facilitar nosso entendimento sobre os aspectos bioquímicos de organismos pretéritos, bem como elucidar sobre os complexos processos tafonômicos envolvidos neste tipo de preservação.

Palavras-chaves: tafonomia, Cretáceo Inferior, Formação Crato, Lagerstätten, componentes orgânicos, Microscopia Eletrônica de Varredura. 


\section{INTRODUCTION}

It is generally assumed that the laminated limestones of the Crato Formation were deposited in a lacustrine environment during Early Cretaceous. This unit outcrops in the northeast side of the Araripe Basin and stands out for being an important paleontological site in northeastern Brazil (Figure 1). The fossils are relatively abundant and diverse, including trace fossils, invertebrates, vertebrates, plants, and palynomorphs (Viana \& Neumann, 2000). Due to the exceptionally preserved biota (Davis \& Martill, 1999; Fielding et al., 2005; Heads et al., 2005; Menon \& Martill, 2007; Silva et al., 2013; Delgado et al., 2014; Barling et al., 2015; Osés et al., 2016, 2017) the Crato Formation is considered a Konservat-Lagerstätte. The Crato Formation represents one of the largest Cretaceous insect deposits in the world, considering both taxonomic diversity and number of individuals (Grimaldi, 1990). In this unit, the following orders are represented: Orthoptera, Isoptera, Homoptera, Hymenoptera, Blattodea, Ephemeroptera, Odonata, Dermaptera, Raphidioptera, Diptera, Trichoptera, Coleoptera, Neuroptera and Heteroptera.

The fossil entomofauna from the Crato Formation is in an exceptional state of preservation, with most of the specimens displaying head, thorax and abdomen including fragile morphological structures such as appendages and wings. Commonly, the insects are three-dimensionally preserved demonstrating indisputably similarities to modern species. Such preservation is fundamental to provide data about the evolution of the insects. Almost all of paleoentomofauna from Araripe Basin occurs within the laminated limestones of Crato Formation. The majority of the fossils have a brown tone due to iron oxides/hydroxides (hematite, goethite, limonite), which replaces the original organic matter, as observed by Menon \& Martill (2007), Delgado et al. (2014), Barling et al. (2015) and Osés et al. (2016). Wang et al. (2012) also documented similar preservation features in Juhol biota insects, northeastern China.
Among the different groups of fossil insects, the Blattodea (cockroaches) are one of the most abundant both in number of described species and number of individuals. Most of cockroach fossils display brown coloration. However, some specimens show a darker hue, as a consequence of certain concentrations of carbon, sulfur and phosphate (Menon \& Martill, 2007). Such substances may be interpreted as the original organic remnants. Mainly hydrocarbons, proteins and lipids (Lockey $\&$ Dularay, 1986) compose the cuticle of modern cockroaches. Over the last decades, attention has been focused on various aspects of the arthropods taphonomy, particularly in our understanding of the environmental circumstances under which exceptional preservation is likely. Nevertheless, taphonomic processes influencing to exceptional preservation are still largely unresolved, although oxygen-deficient bottom water and hypersalinity seem to be important factors in preservation of organic parts of arthropods (Allison, 1988; Briggs, 1991; Briggs \& Kear, 1993; Briggs et al., 1998; Stankiewicz et al., 2000; Babcock et al., 2001; Oliveira et al., 2015). The goal of the present study is to evaluate a 115 million years-old fossil of Araripeblatta dornellesae (Mendes \& Coelho, 2007) (LP/UFC CRT 847) from Crato Formation. Here, we used a large-field scanning electron microscopy (LF-SEM) coupled to energy dispersive spectroscopy (EDS) and Raman spectroscopy to characterize compositional aspects of the fossil at multiple length scales. We chose LP/UFC CRT 847 because it is the only clearly articulated specimen (including antennae, articulated wings and veins) preserved into carbonaceous material. The articulated specimens with open wings and without abdominal deformity indicate that they underwent little transport postmortem (Mendes, 1998; Duncan et al., 2003).

\section{GEOLOGICAL SETTING}

The Araripe Basin is an elongated basin, with a west to east trending, being one of the largest basins in the interior of the Brazilian Northeast (Figure 1). Assine (2007) identified

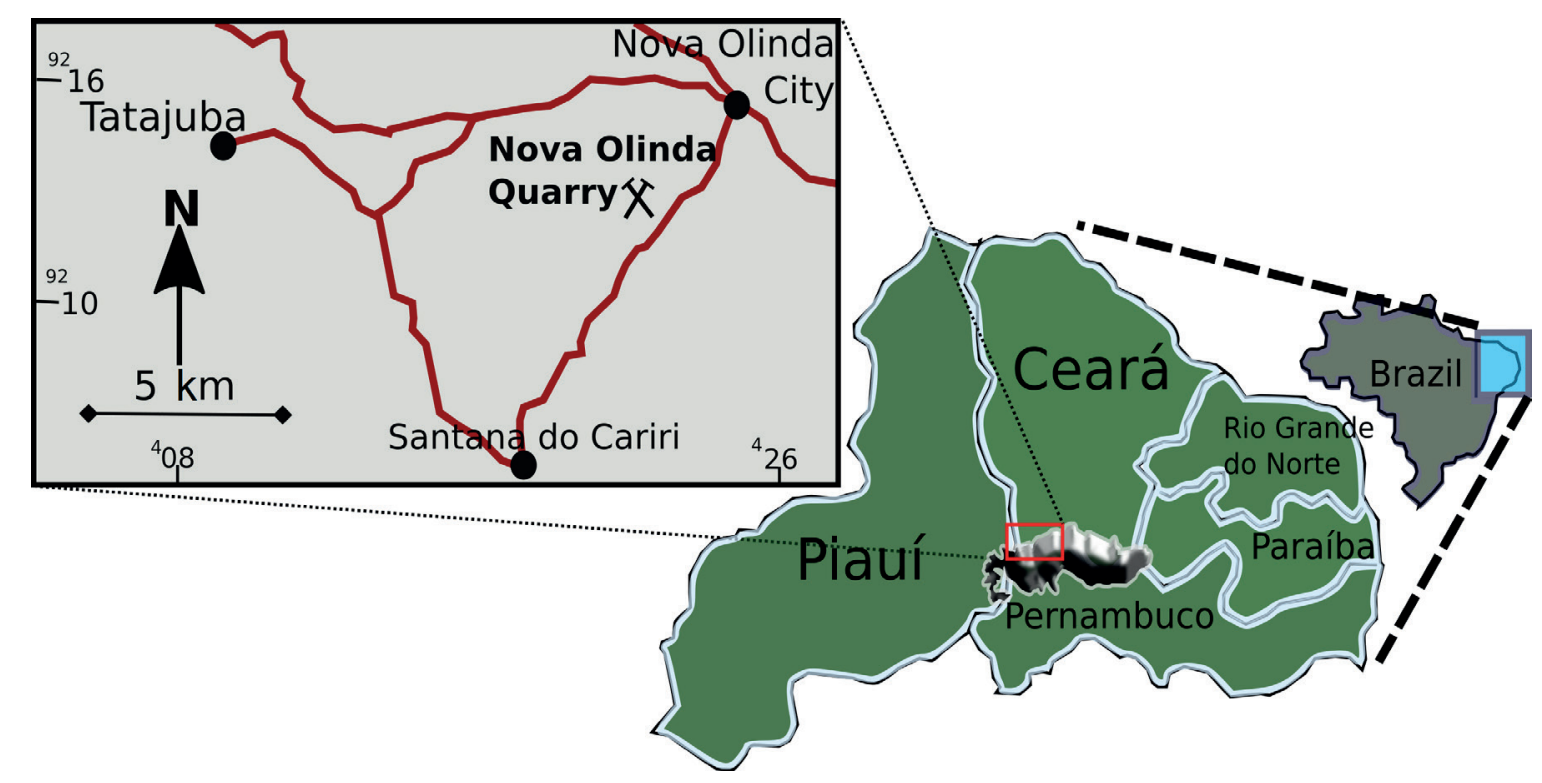

Figure 1. Location of the Araripe Basin in Northeast Brazil and the studied quarry in the Nova Olinda city. Red lines correspond to roads. 
five depositional tectonic-sedimentary sequences limited at the top and bottom by regional discordance: the Paleozoic Sequence; Pre-Rift; Rift; Post-Rift I and Post-Rift II.

The Crato Formation is embedded in the post-Rift I sequence concerning the second lacustrine phase of the Araripe Basin (Assine et al., 2014). This unit comprises sediments around $60 \mathrm{~m}$ thick and consists of carbonates interbedded with a series of claystones, siltstones and sandstones. The laminated carbonate facies represents the wideworld recognized Crato Fossil-Lagerstätte. A restricted lacustrine or lagoonal environment with a stratified water column represents the depositional system. The upper part of the water column was likely well oxygenated, whereas the lake/lagoon bottom was anoxic (Heimhofer et al., 2010). Neumann (1999) suggests that carbonate units represent cyclic pulses controlled by climatic conditions, especially rainfall. The presence of halite pseudomorphs $(\mathrm{NaCl})$ (Martill et al., 2007) is an unequivocal evidence of hypersalinity levels. The Crato Formation is part of the Sergipea variverrucata palynozone, which implies an Aptian age for this unit (Coimbra et al., 2002).

\section{MATERIAL AND METHODS}

\section{Fossil material}

The specimen studied in this work is an adult Blattodea belonging to the species Araripeblatta dornellesae (Figure 2). The fossil is originated from the limestone layers of the Crato Formation, found on Pedra Cariri Quarry in Nova Olinda, State of Ceará, Brazil. The material is deposited in the paleontological collection of the Universidade Federal do Ceará under the code LP/UFC CRT 847.

\section{Analytical approaches}

Raman spectroscopy. This is a very precise technique to determine carbon in several kinds of samples. Carbon may present as graphite, amorphous or disordered structures, among many other possibilities. The Raman spectrum was obtained by a LabRAM HR (Horiba) spectrometer equipped with a liquid N2-cooled CCD detector behind a $600 \mathrm{~g} / \mathrm{mm}$ grating, using $785 \mathrm{~nm}$ laser radiation for excitation ( 2 $\mathrm{mW}$ at the sample surface). The final power at the end of the objective lens (Leica 50x, NA $=0.80$ ) used to focus

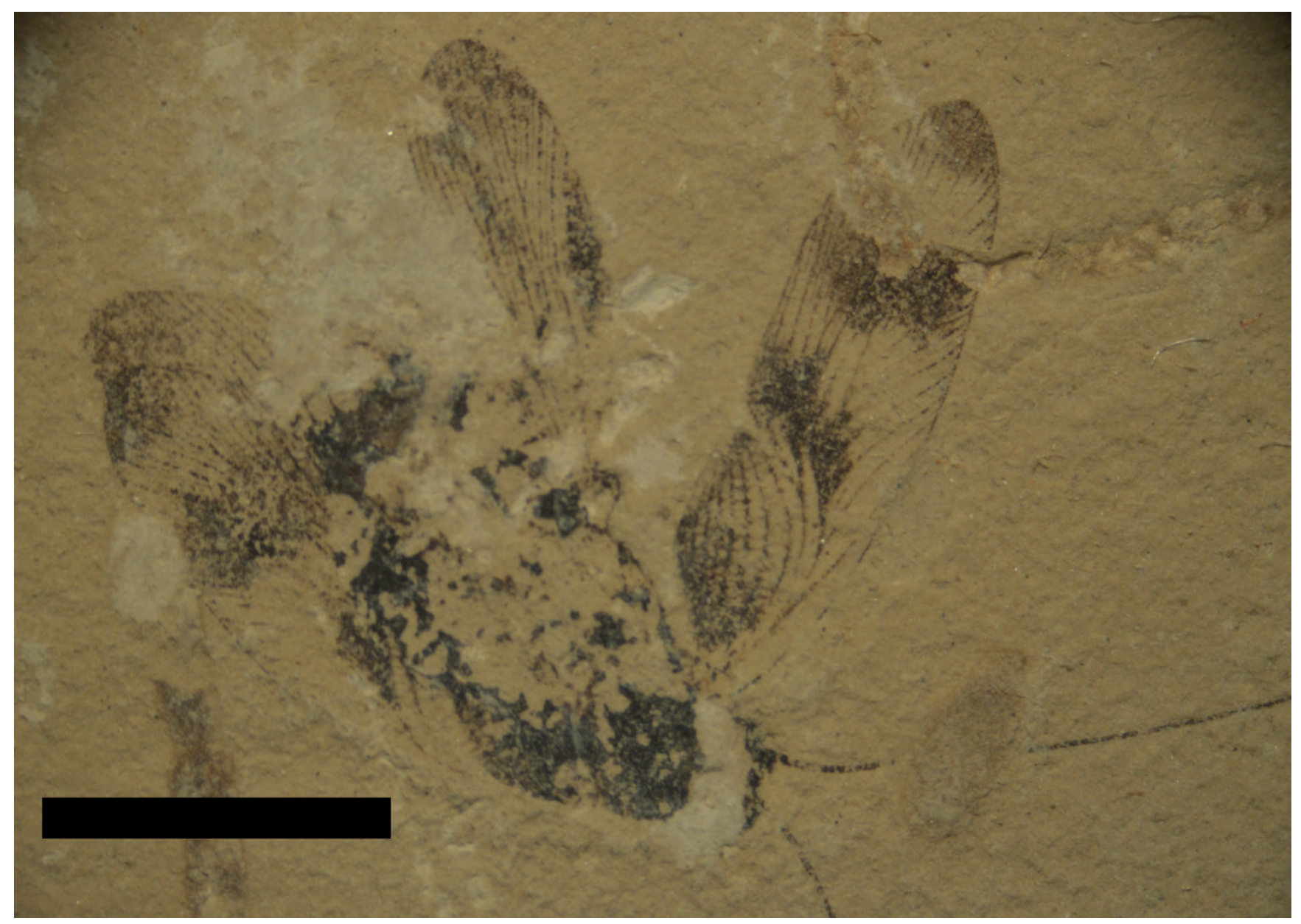

Figure 2. Optical photomicrograph of Araripeblatta dornellesae showing the wings open. Scale bar $=1 \mathrm{~cm}$. 
on the sample surface was $1 \mathrm{~mW}$ with an integration time of $20 \mathrm{~s}$. Raman spectroscopic analyses were performed at the Laboratório de Espectroscopia Vibracional (Physics Department) of the Universidade Federal do Ceará.

Large-field energy dispersive spectroscopy (EDS) and scanning electronic microscopy (SEM) analysis. Large-field scans were performed in an electron microscope Quanta450FEG (FEI) equipped with a gaseous analytical detector (GAD). In addition, an X-ray detector model 150 (Oxford) was used in X-ray energy dispersive spectroscopy (EDS). The specimen was inserted into the SEM without any preparation. Analyses were performed under low vacuum (approximately $100 \mathrm{~Pa}$ with water vapor), by capturing both BSE and X-ray in order to generate the elemental maps. The specimen was scanned at a beam acceleration voltage of 20 $\mathrm{kV}$, with a working distance of $15 \mathrm{~mm}$. SEM/EDS analyses was performed at the Central Analítica of the Universidade Federal do Ceará.

\section{RESULTS}

The cockroach fossil studied here shows well-preserved morphology, with the three tagmata (head, thorax and abdomen) and appendices. According to Duncan et al. (2003), after cockroach death, in 21 days the internal abdominal organs liquefy giving the carcass a swollen appearance. The head separates from thorax after 30 weeks. In addition, the presence of antennae and wings, both anterior and posterior (note all veins), indicate that cockroach underwent little postmortem alteration. Otherwise, the forewing should displays breakage along the $\mathrm{CuP}$ (cubitus posterior) vein (Duncan et al., 2003) (Figure 2).

Elemental mapping of LP/UFC CRT 847 acquired through LF-EDS shows that the fossil is preserved as dark-colored material composed predominantly of carbon (Table 1). The SEM analyses of LP/UFC CRT 847 reveal that the soft-tissue consists of a carbonaceous material without a well-defined microfabric often associated with calcitic filaments (Figure 3).

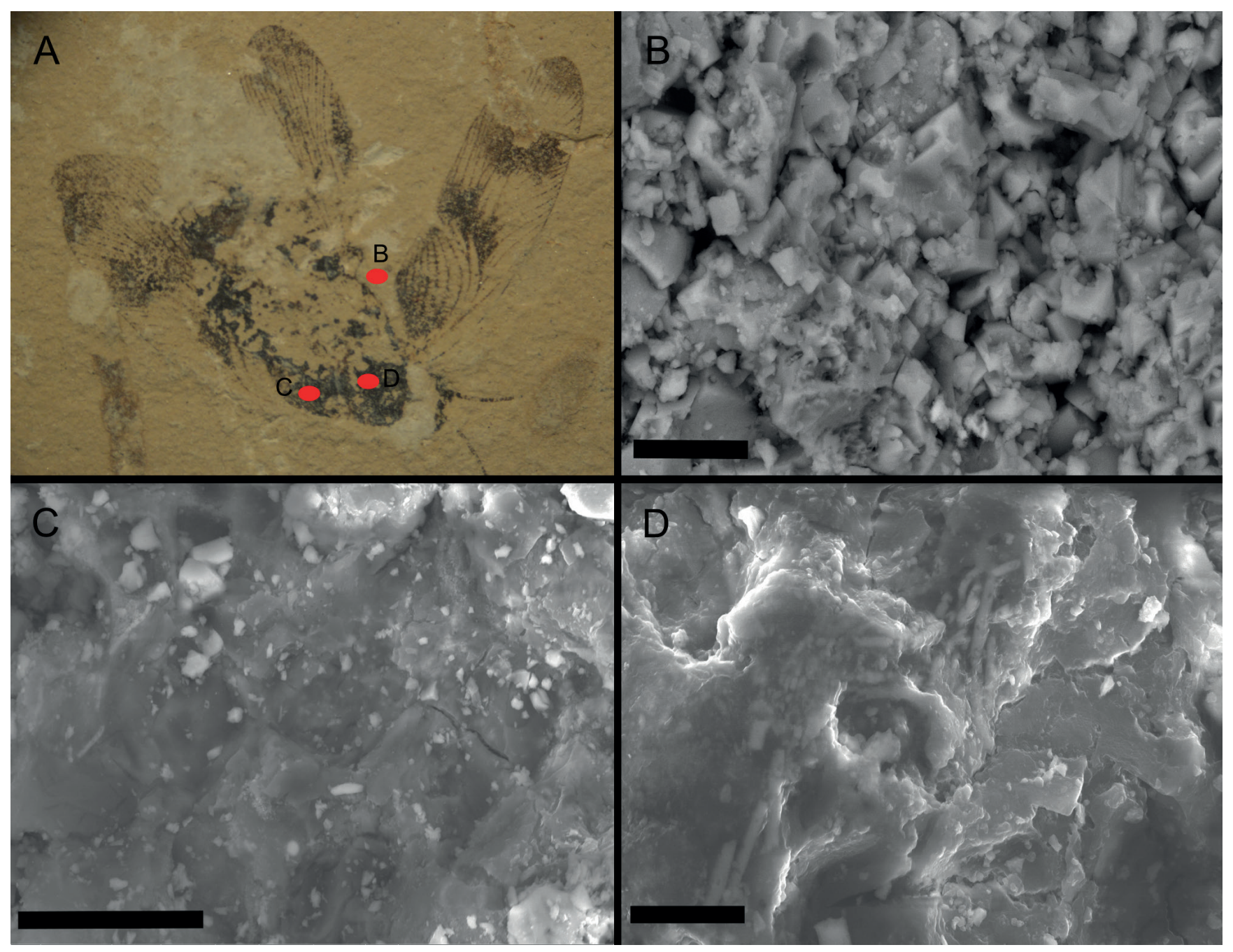

Figure 3. Micrographs of LP/UFC CRT 847. A, specimen with points (B-D) analyzed. B, carbonate matrix with abundant euhedral to subhedral crystallites of calcite. C, scanning electron microscopy secondary electron image of amorphous material occurring consistently along the specimen body. D, micrographs of calcitic filaments associated with LP/UFC CRT 847. Scale bars: B $=10 \mu \mathrm{m} ; \mathrm{C}-\mathrm{D}=5 \mu \mathrm{m}$. 
Elements such as carbon, sulfur and phosphorus are more concentrated on the fossil outline than in the surrounding matrix.

The largest concentrations of carbon (Table 1) occur almost strictly at the body outline. It is present in the fossil in three areas analyzed: wing, antenna and body (Figure 4). EDS indicates carbon concentrations in LP/UFC CRT 847 range from $11 \%$ to $15.2 \%$, the average value is $13.4 \%$. This value is lower than the carbon value of modern Blattodea cuticles, such as Blattella germanica (Kaya et al., 2015). However, this value is higher than average organic carbon for Crato Formation, which is generally less than $1 \%$ according to Catto et al. (2016).

The elemental map for sulfur and phosphorus (Figure 4) shows that both concentrations are higher on the fossil surface than in the surrounding matrix. Sulfur is substantially reduced in the matrix except for a portion near the extended forewing, where the host rock is fractured. The fracture possibly enabled the lateral transfer of organic sulfur from the fossil tissue. The phosphorus was found to be restricted to the interior of the specimen and it was not detected on the wing or on the antennae.
The EDS data shows that calcium is the main element present in the matrix, making clear the contrast between the fossil and the lithological component. The determination of some elements can provide important information about the post-diagenetic changes in the matrix (Heimhofer et al., 2010; Forchielli et al., 2014). The presence of iron and manganese (Figure 5) certainly indicates precipitation of these metals under oxidizing conditions. During the post-diagenetic phase, the precipitation of these metals can promote certain taphonomic distortions contributing to reduction in the quality of preservation of fossils, or even causing their destruction. In this case, $\mathrm{Fe}$ and $\mathrm{Mn}$ distributions are more related to the matrix than to the fossil itself. The high concentrations of these elements (Fe, $\mathrm{Mg}$ and $\mathrm{Mn}$ ) can be verified along a small fracture in the rock (Figure 5).

The presence of carbon is also attested by Raman spectroscopy. The Raman spectrum of the Blattodea fossil (Figure 6) reports two characteristics first order peaks in the region identified as the $\mathrm{D}$ and $\mathrm{G}$ bands, observed respectively at 1331 and $1555 \mathrm{~cm}^{-1}$. The superposition of an intense luminescence background would make it very difficult to obtain the Raman scattering along the sample. Probably,

Table 1. Average weight (\%) of elements contained in the analyzed areas of LP/UFC CRT 847 fossil.

\begin{tabular}{cccccccccccc}
\hline Scanning & \multicolumn{10}{c}{ Element (wt\%) } \\
\cline { 2 - 11 } Areas & $\mathrm{Ca}$ & $\mathrm{C}$ & $\mathrm{F}$ & $\mathrm{Mg}$ & $\mathrm{Si}$ & $\mathrm{S}$ & $\mathrm{Fe}$ & $\mathrm{Al}$ & $\mathrm{Mn}$ & $\mathrm{P}$ \\
\hline Wing & 40.3 & 14.0 & 1.4 & 1.0 & 0.5 & 0.4 & 0.3 & 0.2 & 0.2 & 0.0 \\
Antenna & 40.1 & 11.0 & 1.6 & 1.1 & 0.8 & 0.3 & 0.5 & 0.4 & 0.0 & 0.0 \\
Body & 38.2 & 15.2 & 1.4 & 1.0 & 0.8 & 0.5 & 0.5 & 0.4 & 0.2 & 0.1 \\
\hline
\end{tabular}

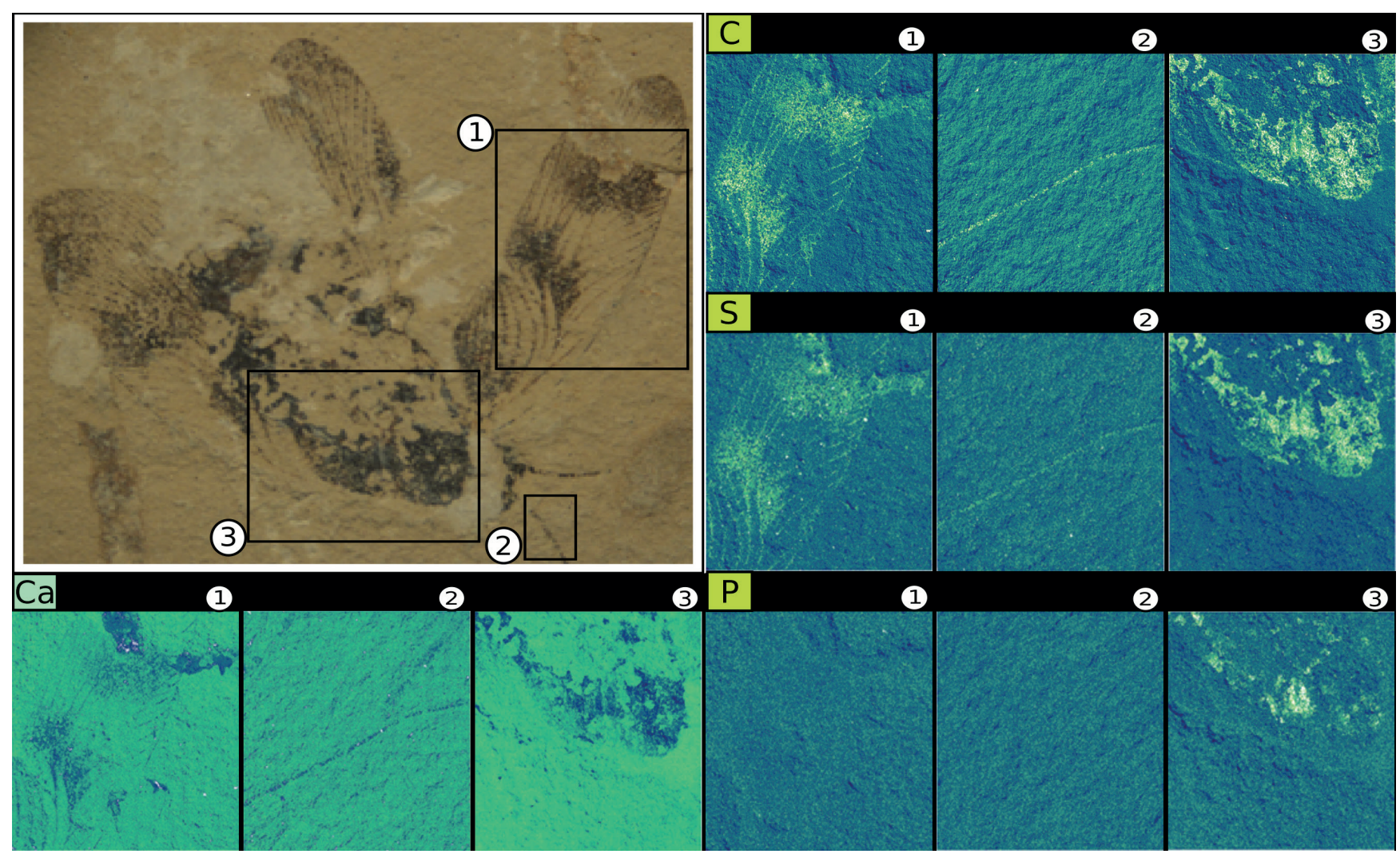

Figure 4. Elemental maps from Blattodea, Crato Formation. Large-Field analyses were performed in three delimited areas 1, 2 and 3 for carbon (C); sulphur (S); phosphorous (P) and calcium $(\mathbf{C a})$. In the map, greenish tones mean presence, whereas blue-dark tones mean absence of element. 


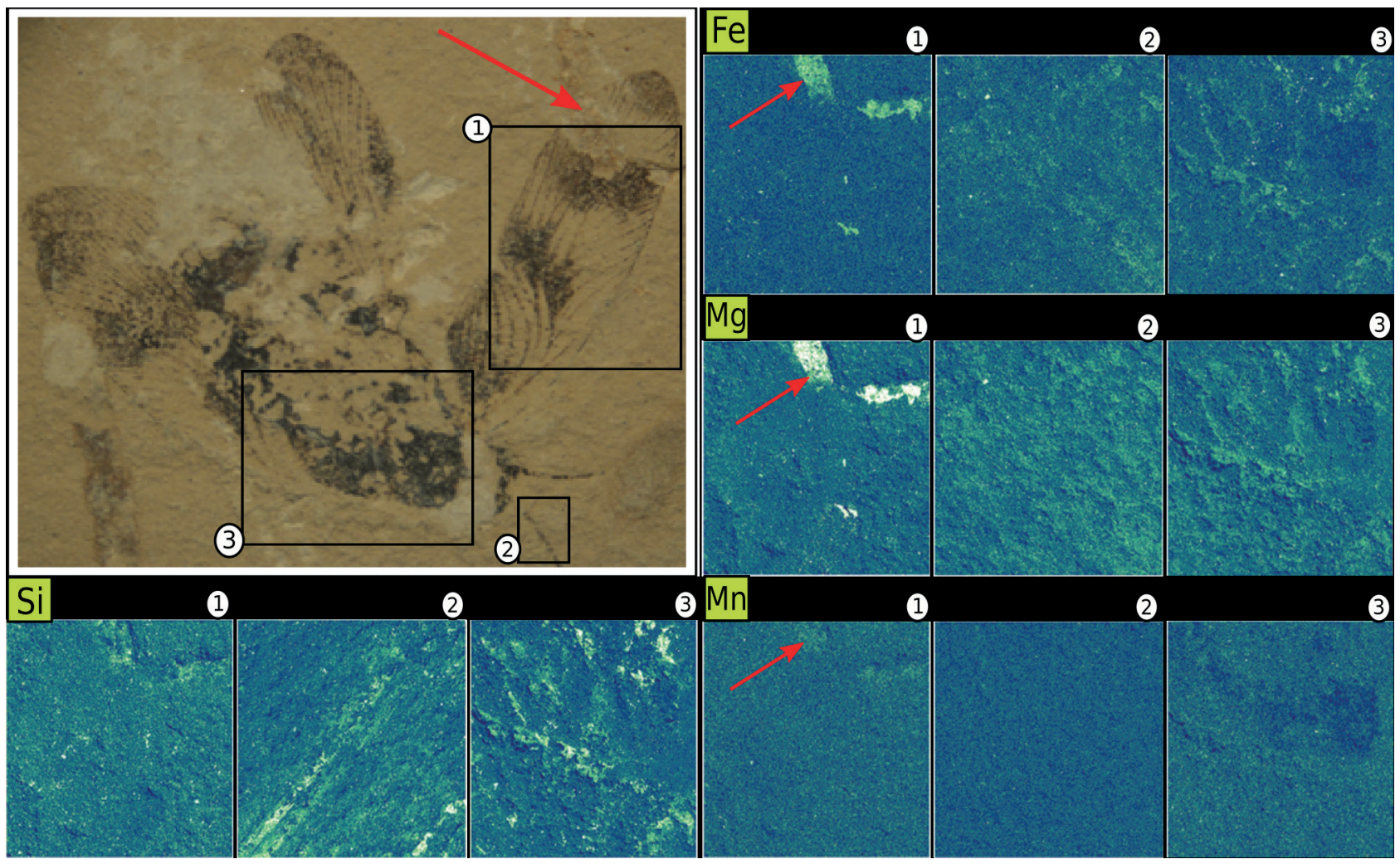

Figure 5. Elemental mapping revealing low inorganic content, $\mathrm{Fe}, \mathrm{Mg}, \mathrm{Mn}$ and $\mathrm{Si}$, in Araripeblatta dornellesae. The greatest concentrations occur along a small fracture near the wing body (as indicated by the red arrow). Greenish tones mean presence, whereas blue-dark tones mean absence of element.

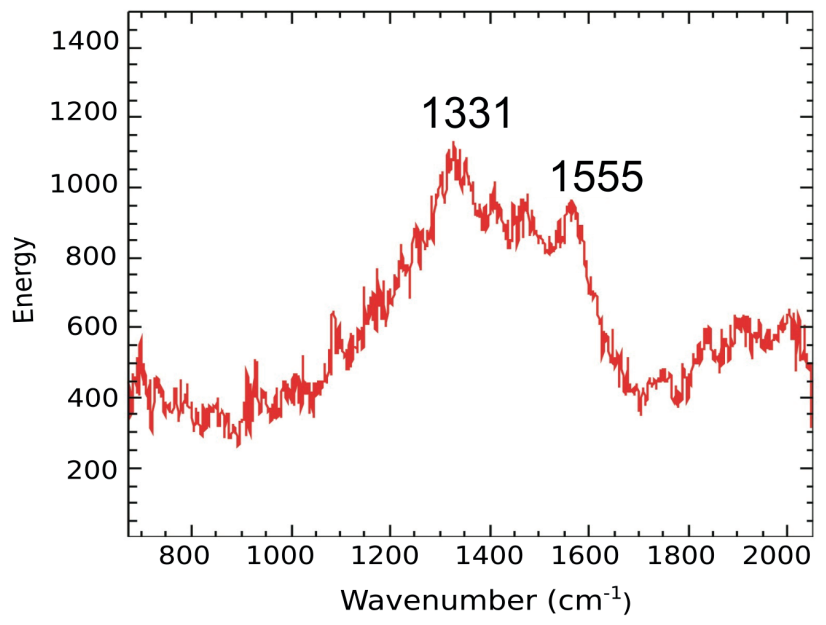

Figure 6. Raman spectrum from LP/UFC CRT 847. The peaks 1331 and $1555 \mathrm{~cm}^{-1}$ are associated with amorphous carbon.

the sample contains excess hydrogen molecules, possibly hydroxyls, which hide the carbon bonds. These two broad peaks confirm the carbon presence in amorphous structure. As pointed out these bands are expected to appear in disordered systems and amorphous carbon.

\section{DISCUSSION}

According to Neumann \& Cabrera (2002), the Crato paleolake had endoreic drainage and was characterized as a meromictic water body containing epilimnion and hypolimnion separated by a pronounced chemocline. Heimhofer \& Martill (2007), suggest that the decomposition of organic matter combined with a permanently stagnant hypolimnion could have caused a reduction in the oxygen available turning the bottom of the water column anoxic. The bacterial decay of organic matter under anaerobic conditions is significantly less efficient and slower than aerobic decomposition. The presence of halite pseudomorphs $(\mathrm{NaCl})$ in the carbonates from Crato Formation (Martill et al., 2007) are further evidence of a depositional system in shallow water under arid conditions. A saline condition caused by evaporation may also have contributed to reduction of oxygen, because the solubility of $\mathrm{O}_{2}$ decreases when salinity increases. Such scenario is has suggested an environment of high salinity and high evaporation rates associated with long dry periods (Martill et al., 2007; Heimhofer et al., 2010; Silva et al., 2013).

These environmental conditions (anoxic and hypersaline water column) associated with a low energy depositional system and gradual carbonate precipitation, created ideal conditions to the preservation of non mineralized tissues 
(Martínez-Delclòs et al., 2004). Thus, insects and other organisms deposited on this site were not severely attacked by bacteria being virtually "frozen".

The Raman spectrum is evidence for the two characteristic peaks already known in the literature as the $\mathrm{G}$ and $\mathrm{D}$ bands. The $\mathrm{D}$ band is originated by resonance processes (being commonly attributed to disorder because of the network disorder). The $G$ peak is due to stretching vibrations of all pairs of $\mathrm{sp}^{2}$ atoms (Ferrari \& Robertson, 2001). Therefore, the peaks 1331 and $1555 \mathrm{~cm}^{-1}$ (Figure 6) indicate that amorphous carbon is present in the Araripeblatta dornellesae. Amorphous carbon was previously observed in a fossil trunk from the Crato Formation (Silva et al., 2013), reinforcing the hypothesis of remaining carbon content. Baas et al. (1995) demonstrated that the aliphatic component encountered in fossil insect tissues is not necessarily the result of migration from an external source. Stankiewicz et al. (2000) and Gupta et al. (2006) interpreted the presence of aliphatic polymer as a product of the polymerization of cuticular lipids. According to Stankiewicz et al. (1997), amorphous character in fossil arthropod cuticles is consistent with polymerization of epicuticular lipids within the cuticle. The $\mathrm{CH}_{4}$ is the unique hydrocarbon generated during diagenesis process. Thus, our results resemble the vertebrate (fish) pyritization-kerogenization model proposed by Osés et al. (2017). In turn, Osés and his colleagues were based on the Ediacaran-Cambrian taphonomic model of Schiffbauer et al., (2014). According to the study of Osés et al. (2017), we considered that LP/UFC CRT 847 undergone preservation by kerogenization (Figure 7).

In addition to carbon, sulfur and phosphorus occurrences are also indicative of original organic remains. The sulfur

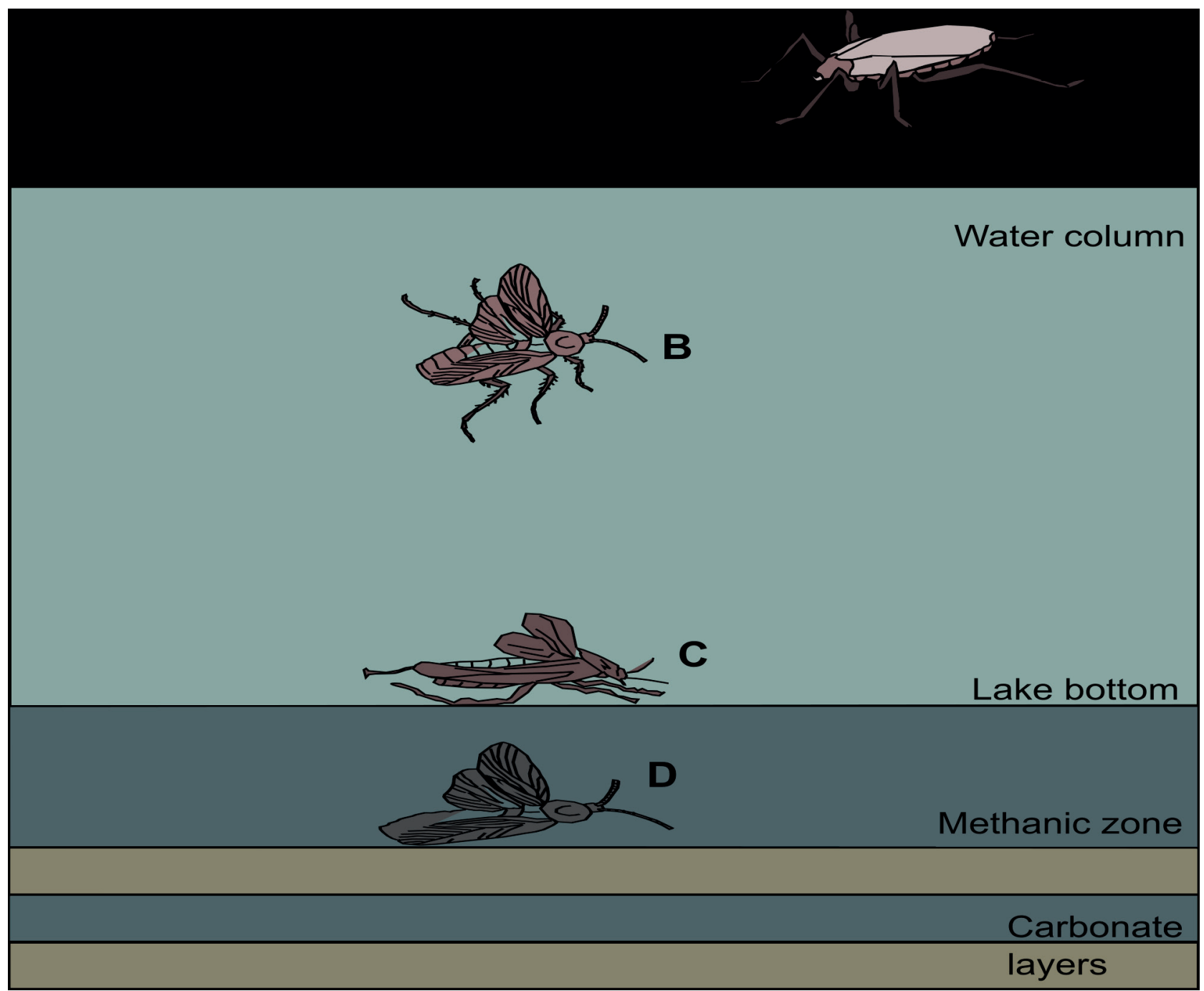

Figure 7. Diagram showing probable LP/UFC CRT 847 taphonomic pathways. A, the specimen must have been dragged into the lake by a number of factors such as flooding, lakefront fires, or even exposure to toxic gases. B, the LP/UFC CRT 847 reached the lake surface still alive; the wings opened attest this (Mendes, 1998). Cockroaches can spend up $36 \mathrm{~h}$ on the water surface (Martínez-Delclòs et al., 2004). It must have been trapped by microbial mats which living in the water column and pulled down. $\mathbf{C}$, at the bottom lake, such a hostile environment caused by oxygen depletion and excessive concentration of salt (it can explain the lack of sediment mixing by benthic organisms) can have prevented the carcass retained the integrity for prolonged periods. $\mathbf{D}$, once in the methanic zone, where decomposition is limited to labile tissues (Konhauser, 2007; Schiffbauer et al., 2014) LP/UFC CRT 847 underwent transformation of organic matter in situ within cuticle. 
concentration is higher along a discontinuity in the host rock. The porosity in the carbonate matrix is millimeter sized making it difficult to percolation of fluids inside. Thus, the fracture behaves as a microzone of lower pressure facilitating the passage of fluids and the precipitation of ions. The phosphorus concentration is low, but previous studies, such as Bergmann et al. (2010), reported a tendency to a higher phosphorus removal in carbonate environments. The co-occurrence of these elements into Blattodea fossil imprint may imply preservation of the original organic components.

This preservation process seems to have occurred through transformation of biopolymers that were transformed into more stable forms during diagenesis (Stankiewicz et al., 1997; Briggs 1999; Wang et al., 2009). Recently, different types of biopolymers have been attributed to different groups of fossil insects. The preservation of organic carbon in LP/UFC CRT 847 implies previous requirements such as rapid burial to avoid disarticulation; the cockroach fossil must have remained for a long period within methanogenetic zone, lower sulfate percolation (see Cai et al., 2012, Schiffbauer et al., 2014, Osés et al., 2017). In the methanogenetic zone, the decomposition is limited by labile tissues due to inability of decomposing heavy organic molecules (Canfield \& Thamdrup, 2009; Schiffbauer et al., 2014). Thus, the carbonaceous preservation is not the product of random repolymerization of organic matter in the sediment, but rather polymerization in situ, within the cuticle during mesodiagenetic stage (Stankiewicz et al., 1998).

The elemental maps also indicate the presence of inorganic compounds related to the host matrix. Silicon probably comes from early diagenesis related to the increase of evaporation and/or decreasing of $\mathrm{pH}$, facilitating the precipitation of silica $\left(\mathrm{SiO}_{2}\right)$. High environmental $\mathrm{CaCO}_{3}$ may explain the high concentration of calcium. Fluor and aluminum are also assigned to the matrix. Manganese, iron, and magnesium are considered geochemically mobile elements. In this case, such elements act as indicators of the degree of post-diagenetic alteration undergone by the host rock and, consequently, of the specimen studied.

\section{CONCLUSIONS}

The preservation of organic remains in fossil results from a complex interaction among biological and geochemical processes that occur sequentially since the death of the organism. The specimen of the Blattodea species Araripeblatta dornellesae analyzed in the present paper displayed the full three tagmata (head, thorax and abdomen) and appendices. The good preservation of the specimen provided important information about the taphonomy of Blattodea in the Crato Formation.

The LF-EDS analysis showed that the presence of amorphous carbon contrasts almost exactly with the distribution of calcium (related to the carbonate matrix). This aspect supports the hypothesis that LP/UFC CRT 847 is preserved into carbonaceous components. Therefore, our results indicate that the vertebrate pyritization-kerogenization model proposed by Osés et al. (2017) can be extended to the insects of the Crato strata. These carbonaceous components potentially provide insights into ancient biology of insects in this unit. Furthermore, the LF elemental maps displayed a series of geochemically derived components that do not correlate with biological structures, in particular, $\mathrm{Mg}, \mathrm{Fe}$ and $\mathrm{Mn}$, which were interpreted as oxides resulting from postdiagenetic percolation fluids.

Here, we worked with only one specimen. Therefore, it is insufficient to propose a general taphonomic model for kerogenized insects. Finally, this study may be considered as a starting point in the investigation of this different preservational mode of insects in the Crato Formation.

\section{ACKNOWLEDGEMENTS}

The authors wish to thank the following Brazilian institutions: Central Analítica and Laboratório de Espectroscopia Vibracional e Microscopia (LEVM) of the Universidade Federal do Ceará. We would also like to acknowledge the Paleontology Laboratory (UFC) for granting access to specimen LPCRT 847. J.H. da Silva, Ph.D., acknowledges the support from the MCTI/CNPQ/Universal $n^{\circ}$ 014/2015. J.H. da Silva also thanks FUNCAP for the support granted through project B.P.I $n^{\circ}$ 03/2018. This study was financed in part by the Coordenação de Aperfeiçoamento de Pessoal de Nível Superior - Brasil (CAPES).

\section{REFERENCES}

Allison, P.A. 1988. Konservat-Lagerstätten: cause and classification. Paleobiology, 14:331-344. doi:10.1017/S0094837300012082

Assine, M.L. 2007. Bacia do Araripe. Boletim de Geociências da Petrobrás, 15:371-389.

Assine, M.L.; Perinotto, J.A.; Neumann, V.H.; Custódio, M.A.; Varejão, F.G. \& Mescolotti, P.C. 2014. Sequências deposicionais do Andar Alagoas (Aptiano superior) da Bacia do Araripe, Nordeste do Brasil. Boletim de Geociencias da Petrobrás, 22:3-28.

Baas, M.; Briggs, D.E.G.; van Heemst, J.D.H.; Kear, A.J. \& de Leeuw, J.W. 1995. Selective preservation of chitin during the decay of shrimp. Geochimica et Cosmochimica Acta, 59:945951. doi:10.1016/0016-7037(95)00012-7

Babcock, L.E.; Zhang, W.T. \& Leslie, S.A. 2001. The Chengjiang Biota: record of the early Cambrian diversification of life and clues to exceptional preservation of fossils. GSA Today, 11:4-9. doi:10.1130/1052-5173(2001)011<0004:TCBROT>2.0.CO;2

Barling, N.; Martill, D.M.; Heads, S.W. \& Gallien, F. 2015. High fidelity preservation of fossil insects from the Crato Formation (lower Cretaceous) of Brazil. Cretaceous Research, 52:605-622. doi:10.1016/j.cretres.2014.05.007

Bergmann, U.; Morton, R.W.; Manning, P.L.; Sellers, W.I.; Farrar, S.; Huntley, K.G.; Wogelius, R.A. \& Larson, P. 2010. Archaeopteryx feathers and bone chemistry fully revealed via synchrotron imaging. Proceedings of the National Academy of Sciences of the United States of America, 107:9060-9065. doi:10.1073/ pnas. 1001569107

Briggs, D.E.G. 1991. Extraordinary fossils. American Science, 79:130-141. 
Briggs, D.E.G. 1999. Molecular taphonomy of animal and plant cuticles: selective preservation and diagenesis. Philosophical Transactions of the Royal Society B:Biological Sciences, 354:7-16. doi:10.1098/rstb.1999.0356

Briggs, D.E.G. \& Kear, A.J. 1993. Decay and preservation of polychaetes: taphonomic thresholds in soft-bodied organisms. Paleobiology, 19:107-135. doi:10.1017/S0094837300012343

Briggs, D.E.G.; Stankiewicz, B.A. \& Evershed, R.P. 1998. The molecular preservation of fossil arthropod cuticles. Ancient Biomolecules, 2:135-146.

Cai, Y.; Schiffbauer, J.D.; Hua, H. \& Xiao, S. 2012. Preservational modes in the Ediacaran Gaojiashan Lagerstätte: pyritization, aluminosilicification, and carbonaceous compression. Palaeogeography, Palaeoclimatology. Palaeoecology, 326328:109-117. doi:10.1016/j.palaeo.2012.02.009

Canfield, D.E. \& Thamdrup, E. 2009. Towards a consistent classification scheme for geochemical environments or, why we wish the term 'suboxic' would go away. Geobiology, 7:385-392. doi:10.1111/j.1472-4669.2009.00214

Catto, B.; Jahnert, R.J.; Warren, L.V.; Varejão, F.G. \& Assine, M.L. 2016. The microbial nature of laminated limestones: lessons from the Upper Aptian, Araripe Basin, Brazil. Sedimentary Geology, 341:304-315. doi:10.1016/j.sedgeo.2016.05.007

Coimbra, J.C.; Arai, M. \& Carreño, A.L. 2002. Biostratigraphy of Lower Cretaceous microfossils from the Araripe Basin, northeastern Brazil. Geobios, 35:687-698. doi:10.1016/S00166995(02)00082-7

Davis, S.P. \& Martill, D.M. 1999. The gonorynchiform fish dastilbe from the lower Cretaceous of Brazil. Palaeontology, 42:715740. doi:10.1111/1475-4983.00094

Delgado, A.O.; Buck, P.V.; Osés, G.L.; Ghilardi, R.P.; Rangel, E.C. \& Pacheco, M.L. 2014. Paleometry: a brand new area in Brazilian science. Materials Research, 17:1434-1441. doi:10.1590/15161439.288514

Duncan, I.J.; Titchener, F. \& Briggs, D.E.G. 2003. Decay and disarticulation of the cockroach: implications for preservation of the blattoids of Writhlington (Upper Carboniferous), UK. Palaios, 18:256-265. doi:10.1669/0883-1351(2003)018<0256

Ferrari, A.C. \& Robertson, J. 2001. Resonant Raman spectroscopy of disordered, amorphous, and diamond like carbon. Physical Review, 64:75414. doi:10.1103/PhysRevB.64.075414

Fielding, S.; Martill, D.M. \& Naish, D. 2005. Solnhofen-style soft-tissue preservation in a new species of turtle from the Crato Formation (early cretaceous, aptian) of north-east Brazil. Palaeontology, 48:1301-1310. doi:10.1111/j.14754983.2005.00508.x

Forchielli, A; Steiner, M.; Kasbohm, J.; Hu, S. \& Keupp, H. 2014. Taphonomic traits of clay-hosted early Cambrian Burgess Shale-type fossil Lagerstätten in South China. Palaeogeography, Palaeoclimatology, Palaeoecology, 398:59-85. doi:10.1016/j. palaeo.2013.08.001

Grimaldi, D.A. 1990. Insects from the Santana Formation, Lower Cretaceous, of Brazil. New York, American Museum Natural History, 191 p. (Bulletin 195).

Gupta, N.S.; Michels, R.; Briggs, D.E.G.; Evershed, R.P. \& Pancost, R.D. 2006. The organic preservation of fossil arthropods: an experimental study. Philosophical Transactions of the Royal Society B: Biological Sciences, 273:2777-2783. doi:10.1098/ rspb.2006.3646

Heads, S.W.; Martill, D.M. \& Loveridge, R.F. 2005. An exceptionally preserved antlion (Insecta, Neuroptera) with colour pattern preservation from the Cretaceous of Brazil. Palaeontology, 48:1409-1417. doi:10.1111/j.1475-4983.2005.00514.x
Heimhofer, U.; Ariztegui, D.; Lenninger, M.; Hesselbo, S.P.; Martill, M.D. \& Rios-Netto, A.M. 2010. Deciphering the depositional environment of the laminated Crato fossil beds (Early Cretaceous, Araripe Basin, Northeastern Brazil). Sedimentology, 57:677-694. doi:10.1111/j.1365-3091.2009.01114.x

Heimhofer, U. \& Martill, D.M., 2007. The sedimentology and depositional environment of the Crato Formation. In: D.M. Martill; G. Bechly \& R.F. Loveridge (eds.) The Crato Fossil Beds of Brazil - Window into an ancient world, Cambridge University Press, p. 44-63.

Kaya, M.; Baublys, V.; Sargin, I.; Šatkauskienè, I.; Paulauskas, A.; Akyuz, B.; Bulut, E.; Tubelyte, V.; Baran, T.; Kabalak, M. \& Yurtmen, H. 2015. How taxonomic relations affect the physicochemical properties of chitin. Food Biophysics, 11:10 19. doi:10.1007/s11483-015-9404-5

Konhauser, K. 2007. Introduction to Geomicrobiology. Malden, Blackwell Publishing, 349 p.

Lockey, K.H. \& Dularay, B. 1986. Cuticular methylalkanes of adult cockroaches, Blatta orientalis and Periplaneta americana. Comparative Biochemistry and Physiology, 85:567-572. doi:10.1016/0305-0491(86)90048-9

Martill, D.M.; Loveridge, R.F. \& Heimhofer, U. 2007. Halite pseudomorphs in the Crato Formation (Early Cretaceous, Late Aptian-Early Albian), Araripe Basin, Northeast Brazil: further evidence for hypersalinity. Cretaceous Research, 28:613-620. doi:10.1016/j.cretres.2006.10.003

Martínez-Delclòs, X.; Briggs, D.E.G. \& Peñalver, E. 2004. Taphonomy of insects in carbonates and amber. Palaeogeography, Palaeoclimatology, Palaeoecology, 203:19-64. doi:10.1016/ S0031-0182(03)00643-6

Mendes, M. 1998. An attempt at taphonomic simulation in Blattopteras from Araripe (Lower Cretacean) from the NE of Brazil. In: INTERNACIONAL PALAEOENTOMOLOGICAL CONFERENCE, 1, 1998. Proceedings, Moscow, p. 99-103.

Mendes, M. \& Coelho, L.A. 2007. Novas baratas (Insecta, Blattodea, Blattidae) da Formação Santana, Cretáceo Inferior, Nordeste do Brasil. In: I.S. Carvalho; R. Cassab; C. Schwanke; M.A. Carvalho; A.C. Fernandes; M.A. Rodrigues; M.S. Carvalho; M. Arai \& M. Oliveira (eds.) Paleontologia: cenários de vida, Interciência, p. 457-465.

Menon, F. \& Martill, D.M. 2007. Taphonomy and preservation of Crato Formation arthropods. In: D.M. Martill; G. Bechly \& R.F. Loveridge (eds.) The Crato fossil beds of Brazil - Window into an ancient world, Cambridge University Press, p. 79-94.

Neumann, V.H. 1999. Estratigrafia, sedimentología, geoquímica y diagénesis de los sistemas lacustres aptienses-albienses de la Cuenca de Araripe (Noreste de Brasil). Universidad de Barcelona, Ph.D. thesis (unpublished), 233 p.

Neumann, V.H. \& Cabrera, L. 2002. Características hidrogeológicas gerais, mudanças de salinidade e caráter endorréico do sistema lacustre Cretáceo do Araripe, NE Brasil. Revista de Geologia, 15:43-54.

Oliveira, N.C.; Silva, J.H.; Barros, O.C.; Pinheiro, A.P.; Santana, W.; Saraiva, A.A.; Ferreira, O.P.; Freire, P.T.C. \& Paula, A.J. 2015. Large-field electron imaging and X ray elemental mapping unveil the morphology, structure, and fractal features of a Cretaceous fossil at the centimeter scale. Analytical chemistry, 87:10088-10095. doi:10.1021/acs.analchem.5b02815

Osés, G.L.; Petri, S.; Becker-Kerber, B.; Romero, G.R.; Rizzutto, M.A.; Rodrigues, F.; Galante, D.; Silva, T.F.; Curado, J.F.; Rangel, E.C.; Ribeiro, R.P. \& Pacheco, M.L. 2016. Deciphering the preservation of fossil insects: a case study from the Crato Member, Early Cretaceous of Brazil. PeerJ, 4:e2756. doi:10.7717/peerj.2756 
Osés, G.L.; Petri, S.; Voltani, C.G.; Prado, G.M.; Douglas, G.; Rizzutto, M.A.; Rudnitzki, I.D.; Silva, D.; Rodrigues, F.; Rangel, E.C., Sucerquia, P.A. \& Pacheco, M.L. 2017. Deciphering pyritization-kerogenization gradient for fish soft-tissue preservation. Scientific Reports, 7:1468. doi:10.1038/s41598017-01563-0

Schiffbauer, J.D.; Xiao, S.; Cai, Y.; Wallace, A.F.; Hua, H.; Hunter, J.; Xu, H.; Peng, Y. \& Kaufman, A.J. 2014. A unifying model for Neoproterozoic-Palaeozoic exceptional fossil preservation through pyritization and carbonaceous compression. Nature Communications, 5:5754. doi:10.1038/ncomms6754

Silva, J.H.; Freire, P.T.C.; Abagaro, B.T.; Silva, J.A.; Saraiva, G.D.; Lima, F.; Barros, O.A.; Bantim, R.A.; Saravia, A. \& Viana, B. 2013. Spectroscopic studies of wood fossils from the Crato Formation, Cretaceous period. Spectrochimica Acta, 115:324-329. doi:10.1016/j.saa.2013.06.042

Stankiewicz, B.A.; Briggs, D.E.G. \& Evershed, R.P. 1997. Chemical composition of Paleozoic and Mesozoic fossil invertebrate cuticles as revealed by pyrolysis-gas chromatography/mass spectrometry. Energy \& Fuels, 11:515-521. doi:10.1021/ ef 9601778

Stankiewicz, B.A.; Briggs, D.E.G.; Michels, R.; Collinson, M.E. \& Evershed, R.P. 2000. Alternative origin of aliphatic polymer in kerogen. Geology, 28:559-562. doi:10.1130/00917613(2000)28<559:AOOAPI $>2.0 . C O ; 2$
Stankiewicz, B.A.; Scott, A.C.; Collinson, M.E.; Finch, P.; Mösle, B.; Briggs, D.E.G. \& Evershed, R.P. 1998. Molecular taphonomy of arthropod and plant cuticles from the Carboniferous of North America: implications for the origin of kerogen. Journal of the Geological Society, 155:453-462. doi:10.1144/gsjgs. 155.3.0453

Viana, M.S. \& Neumann, V.H. 2000. Membro Crato da Formação Santana, Chapada do Araripe, CE. Riquíssimo registro de fauna e flora do Cretáceo. In: C. Schobbenhaus; D.A. Campos; E.T. Queiroz; M. Winge \& M.L.C. Berbert-Born (eds.) Sítios geológicos e paleontológicos do Brasil, 5. Departamento Nacional da Produção Mineral/Companhia de Pesquisa de Recursos Minerais/Comissão Brasileira de Sítios Geológicos e Paleobiológicos, p. 113-120.

Wang, B.; Li, J.F.; Fang, Y. \& Zhang, H.C. 2009. Preliminary elemental analysis of fossil insects from the Middle Jurassic of Daohugou, inner Mongolia and its taphonomical implications. Chinese Science Bulletin, 54:783-787. doi:10.1007/s11434008-0561-5

Wang, B.; Zhao, F.; Zhang, H.; Fang, Y. \& Zheng, D. 2012. Widespread pyritization of insects in the early cretaceous jehol biota. Palaios, 27:707-711. doi:10.2110/palo.2012.p12-029r

Received in 29 March, 2018; Accepted in 20 October, 2018. 